Review Article

www.ijrap.net

\title{
EFFICACY OF DURVADI TAILA AND AVGAHANA SWEDA BY DRAVYA OF NAYOGRADHADI GANA IN THE MANAGEMENT OF PARIKARTIKA WITH SPECIAL REFERENCE TO FISSURE-IN-ANO: A REVIEW
}

\author{
Chandrakar Smriti ${ }^{1 *}$, Rajpoot Purnima ${ }^{1}$, Sahu Purnesh ${ }^{1}$, Singh Balendra ${ }^{2}$ \\ ${ }^{1}$ M.S. Scholar, PG Department of Shalya Tantra, Government Ayurvedic College, Raipur, Chhattisgarh, India \\ ${ }^{2}$ Reader, PG Department of Shalya Tantra, Government Ayurvedic College, Raipur, Chhattisgarh, India
}

Received on: 10/12/16 Revised on: 20/01/17 Accepted on: 22/02/17

*Corresponding author
E-mail: dr.smritichandrakar@gmail.com

DOI: $10.7897 / 2277-4343.0814$

\section{ABSTRACT}

Ayurveda is an age-old science which emphasize on the health then to cure the diseases. Modernize life is full of hurry-worry-curry life leads Agnimandya then constipation. Constipation is one of the major cause of this notorious diseases called fissure-in-ano. Fissure is a type of wound made by hard stool(constipation) with associated symptoms of burning variety of pain and bleeding during defecation. Healing of wound is a physiological process but as it is more prone to infection that results in delay repair. Acute fissure can be treated by Oushadha chikitsa and Pathya sevana. Durvadi taila for local application \& Dravya of Nyogradhadi gana for avagahana has an excellent result in wound healing in acute condition where as for the chronic fissure; surgical involvement i.e. lateral sphincterotomy is the treatment of choice.

Keywords: Constipation, fissure, wound healing, Agnimandya

\section{INTRODUCTION}

Today's life is very fast \&stressful. People are unable to follow swasthvritta ${ }^{1} \&$ sadvritta paricharya ${ }^{1}$. In Ayurvedic treatise it's precisely stated that if one follows sadvritta \& swasthvritta; they are never affected by diseases. But hectic schedule of people leads irregular eating and sleeping habits, vega-dharana, smoking, drinking \& mental stress all causes several disharmonies in biological system of human being. Vagbhatta depicted that diseases are consequence of mandagni ${ }^{2}$ which leads to Vibandha (constipation). Constipation is an ailment with multi-factorial etiology and diverse symptoms ${ }^{3}$. It is one of the major feature of disorder of colorectal motility. ${ }^{3}$ Constipated people are unable to pass stool or pass hard stool which breaks the smooth wall of anal verge or longitudinal tear in lower end of anal canal ${ }^{4}$ this condition is called Parikartika (fissure-inano). Fissure-in-ano is very commonly encountered in day to day practice. It affects all age groups especially adult age $\&$ both sexes are equally affected but more common in females ${ }^{5}$. Fissure-in-ano is very common to cause substantial morbidity in human who are otherwise healthy. Spasm of anal sphincter causes fissure. Predominant symptom of anal fissure is excruciating pain, stool streak of blood and burning sensation. Comparatively, pain is more in acute type of fissure. It has been postulated that fissure may occur due to trauma to the anoderm and spasm of internal sphincter. Problem of complication after surgery and recurrence after medical treatment of fissure-in-ano still gives a wide scope for consideration to evolve newer methods of management of this ailment. These drawbacks in the management of fissure-in-ano have provided scope for adopting principles of Ayurveda. ${ }^{6}$

Charaka described it as vamanvirechana-vyapad ${ }^{7}$, Bastivyapad $^{8}$, bastinetravyapad ${ }^{9}$. Sushruta documented Parikartika as Virechana vyapad ${ }^{10} \&$ Basti vyapad ${ }^{11}$. Vagbhatta enumerated it as Upadrava (complication) of Vataja atisara $^{12}$ (diarrhea) \& Kashyapa depicted the diseases is prevalently seen in gravid women ${ }^{13}$. Cardinal sign \& symptom is kshata-guda (tear in anoderm), vedana (severe pain), raktastrava (hemorrhage).

\section{Definition}

Cutting \& tearing pain everywhere is called fissure in ano. ${ }^{14}$

${ }^{15}$ Pari = sarvato bhaavahan

Parikrit $=$ krintati - to cut off; cut round

Kartika $=$ Sharp shooting pain (especially in the rectum)

Kartana $=$ to cut off

Fissure is common diseases of anus which causes an amount of suffering out of all proportion to the size of lesion. A fissure consists essentially of a crack in skin line part of anal canal which often shows a considerable reluctance to heal. ${ }^{16}$

Anal fissure is an acute superficial break in the continuity of ano-derma usually in post midline of anal margin. ${ }^{17}$

\section{Site of fissure ${ }^{18}$}

Examination of lower half of anal canal by separation of buttocks to open the perianal area will reveal presence of any simple anal fissure as it is located below the dentate line and is always confined to the ano-derma in mid line posterior position or mid line anterior position. In male, it is found mid line posteriorly $(90 \%)$, mid line anteriorly $(10 \%)$ where as in female - mid line posteriorly (60\%), mid line anteriorly (40\%). Exceptionally it is found elsewhere on the circumference of the anus.

Synonyms

Anal ulcer, Anal fissure, Ulcer in ano , Fecal ulcer

\section{Cause of anal fissure ${ }^{4}$}

Hard stool (constipation), Inflammatory bowel diseases, parturition, person taking purgatives for long, trauma around 
anal verge by speculum, enema., secondary diseases like HIV, TB, STD and Syphilis.

Types

Acharya Kashyapa described the type of Parikartika based on dosha predominance ${ }^{12} \&$ character of pain in anal canal-

- Vatika - Shooting, cutting type of pain

- Paittika - Burning type of pain

- Shleshmika - Itching type of pain

In modern classification fissure, can be divide in 2 types-
- Primary or idiopathic

- Secondary to other diseases or surgery

Fissure can also have classified as ${ }^{19}$

- Acute Fissure - This ulcer is often in epithelial surface but never the less may cause severe pain and spasm. It has history of less than 6 weeks.

- Chronic fissure- In chronic cases where deep scar, induration of edge of fissure present, fiber of internal sphincter exposed. It has history of more than 6 weeks.

Probable Samprapti

Nidana - Inappropriate oushadha (medicine) in virechana (purgation) bastivyapad (complication of enema) and

bastinetra vyapad

$\downarrow$

Agni dushti

$\downarrow$

Vitiation of Vata pitta dosha

$\downarrow$

Avipaka and malsanchaya

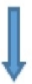

Apanvayuprakopa

$\downarrow$

Dushti of Purish-vaha srotas and dushya Twaka, Mamsa ,Rakta

Mal sanga and kha- vaigunya

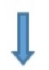

Dosha- dushya Samurchhana

Increases rukshata of mala

$\downarrow$

Ruksha mala leads guda-vidar

i.e. Parikartika (fissure- in- ano) 
Symptoms ${ }^{16}$

1) Pain - cutting, burning, itching type

2) Bleeding - slight but occasionally profuse

3) Discharge \& pruritus- if much discharge present leads moisture of peri-anal skin cause itching.

4) Bowel habits - tendency to going to stool is defer, constipation

5) Nervous manifestation-abdominal discomfort, headache, irritability
Treatment

Dravya of nayogradhadi gana- ${ }^{20}$

Mode of Application - Awagahana Sweda (hot water sitz bath)

Sitting in the hot water after each bowel movement soothes pain and relaxes spasm of sphincter for some time $\mathrm{e}^{21}$.avagahan is done for 10-15 minute. It is one of the best remedy for Parikartika to relief pain and cleaning of wound.

Table 1a: Contents of Nyagrodhadi Gana

\begin{tabular}{|c|c|c|}
\hline Drug & Botanical name & Action \\
\hline Vata $^{22}$ & Ficus bengalensis & $\begin{array}{c}\text { Vrana-ropana, kshata-ropana (wound healing), vedana sthapana (analgesic), Shothahara (anti- } \\
\text { inflammatory), Rakta-rodhaka (hemostatic) }\end{array}$ \\
\hline Udumbara $^{23}$ & Ficus glomerata & Vedana sthapana, Shothahara, Vrana-ropana, daha-prashmana (reduces burning) \\
\hline Aswatha $^{24}$ & Ficus religiosa & Vrana ropana, Vedana-sthapana, Shothahara, raktaarodhak \\
\hline Parisha $^{25}$ & Thespesia populenea & Kapha-pitta shamka, raktashodhaka (blood purifier), shothhara, stambhaka (styptic) \\
\hline Plaksha $^{26}$ & Ficus lacor & Kapha pitta shamka, Rakta shodhaka, shothahara \\
\hline
\end{tabular}

Durvadya taila - (Chakradatta vranashotha/91 $)^{27}$

Mode of application - Apply locally

Table 1b: Contents of Durvadya taila

\begin{tabular}{|c|c|c|c|c|}
\hline Name of Drug & Doshkarma & Karma & Rogaghanata & Pharmacological activity \\
\hline Durva $^{28}$ & $\begin{array}{c}\text { Kapha-pitta } \\
\text { shamak }\end{array}$ & $\begin{array}{c}\text { Stambhana, Vrana-ropana, } \\
\text { daha prashamana, varnya }\end{array}$ & $\begin{array}{c}\text { Kshata (abrasion), Vrana (wound), } \\
\text { arsha (hemorrhoids), shitpitta } \\
\text { (urticaria) }\end{array}$ & $\begin{array}{c}\text { wound healing, antiviral, } \\
\text { antifungal, antimicrobial }\end{array}$ \\
\hline Kampillaka $^{29}$ & $\begin{array}{c}\text { Kaphavata } \\
\text { shamak }\end{array}$ & $\begin{array}{c}\text { kusthaghna, vranashodhana, } \\
\text { vranaropan, dipana, Rechana }\end{array}$ & $\begin{array}{c}\text { kshat, kandu (itching), Shoola } \\
\text { (pain), shopha (inflammation) }\end{array}$ & $\begin{array}{c}\text { purgative, anti-inflammatory, } \\
\text { wound healing, } \\
\text { antimicrobial }\end{array}$ \\
\hline Daruharidra $^{30,31}$ & $\begin{array}{c}\text { Kapha pitta } \\
\text { shamka }\end{array}$ & $\begin{array}{c}\text { shothhara,vednasthapana, } \\
\text { vranashodhana, Agnimandya }\end{array}$ & $\begin{array}{c}\text { Vrana, kandu } \\
\text { antifinflinglammatory } \\
\text { antia, }\end{array}$ \\
\hline Tila Taila $^{32}$ & $\begin{array}{c}\text { Vatakapha } \\
\text { shamka }\end{array}$ & $\begin{array}{c}\text { twakprasadan, Vrana-ropana, } \\
\text { vranashodhana }\end{array}$ & vanaroga & \\
\hline
\end{tabular}

For the treatment of Parikartika- Avagahan by Dravya of Nayogradhadigana \& Durvadyataila for local application is may be beneficial due having some following property-
a. Kusthaghana
b. Vranaropan
c. Kshatropan
d. Vednasthapan
e. Shothahara
f. Rakta-shodhaka
g. Stambhana

Chronic Fissure - It is canoe-shaped ulcer with thick oedematous margins at upper end hypertrophied papilla \& lower end sentinel tag present, inflammation and induration at margins. Base consists of scar tissue and internal sphincter muscle spasm. For treatment of chronic fissure lateral internal sphincterotomy is best result. ${ }^{33}$

\section{Lateral Sphincterotomy}

Patient kept in lithotomy position. with antiseptic \& aseptic precaution painting \& draping should be done. The point of blade inserted through the perianal skin $\rightarrow$ lateral to lower edge of internal sphincter $\rightarrow$ passed vertically upward to intersphincteric plane till it is adjusted to lie at the level of pectinate line $\rightarrow$ blade in direction of anal canal the lower half of internal sphincter is divided. The result is faster healing fissure \& immediate relief pain. Incontinence and soiling of underclothes with muco-fecal discharge are main complication of surgery.

\section{DISCUSSION}

Nidana parivarjana (avoid the causative factor) is first and foremost step of treatment. Dravya of Nyogradhadi gana (vata, udumber, ashwattha, parish, plaksha) are having vranashodhana, Vrana-ropana, Shotha-hara, Vedana-sthapana properties. The drugs having kashaya rasa \& shita veerya which intern helps in reducing daha and layover Rakta (blood). Parish and Plaksha having kapha pitta shamaka properties which help to stop pus formation and interrupt daha. For chronic fissure, lateral sphincterotomy i.e. in inter-sphincteric groove just inside of anal verge blunt dissection done to free internal sphincter leads lowering resting pressure of internal anal sphincter which improve blood supply to fissure and allow faster healing, early convalescence. Durva have stambhana, Vrana-ropana, vraya, daha prashamana, raktasthambhana (hemostatic) quality. Kamppillaka has Vrana-ropana and kusthaghana properties which help to reduce itching and start healing of wound. Shothahara, Vedana sthapana (analgesic), Vrana-shodhana, Vranaropana quality of Daruharidra; reduces pain and heals wound. Tila taila give smoothening effect with Vrana-ropana (wound healing).

\section{CONCLUSION}

Major population worldwide encounters Fissure-in-ano now-adays. It is caused by vitiation of vata and pitta dosha, improper application of Pancha-karma and modernized life style are some of the key. The patho-physiology is based on high sphincter pressure and management is generally aimed toward reducing 
anal pressure. The treatment of fissure-in-ano by avagahana (hot water sitz bath) using dravya (contents) of nayogradhadi gana and local application of durvadya taila (medicated oil) help to relief symptoms like pain, bleeding, itching resulting in wound healing. Lateral sphincterotomy remains the gold standard for definitive management of chronic fissure-in-ano but there may be high risk of incontinence.

\section{REFERENCES}

1. Agnivesha, Charaka Samhita, revised by Charaka and Dridhbala with "Ayurveda Dipika" commentary by Chakrapani, Edited by Vaidya Yadavji Trikamji Acharya, Published by Chaukhambha Publications, Varanasi, edition$5^{\text {th }}$ Year of reprint 2001, Sutrasthana 30/26, p- 187

2. Vagbhatta, Ashtanga Hridaya, revised by Vidyotini Hindi commentary by Kaviraja Atrideva Gupta, Edited by Vaidya Yadunandana Upadhyaya, Published by Chaukhambha Sanskrit Sansthan, Varanasi, Edition 3, Year of publication Vi.S.201, Sutrasthana 4/, pg no. 535

3. International Journal of Advances in Pharmacy Biology Chemistry, Constipation and Ayurvedic Churna for its treatment by P. S. Borhade, TA Deshmukh, IJAPBS Volume 2(1), Jan-mar. 2013.

4. Manipal manual of Surgery $2^{\text {nd }}$ edition, chapter 131 , page no. 531 .

5. A concise textbook of surgery by Dr. Somen Das, $8^{\text {th }}$ edition, chapter 45, page 1083 .

6. Peshala KKVS et al; A study of anal sphincter tone in acute fissure in ano patients treated with Mahanarayan taila; Int. J. Res. Ayurveda Pharm.5(3), May-June-2014; doi: 10.78972277-4343.05365

7. Agnivesha, Charaka Samhita, revised by Charaka and Dridhbala with "Ayurveda Dipika" commentary by Chakrapani, Edited by Dr. Bramhanand Tripathi, Acharya, Published by Chaukhamba Surbharati Prakashan, Varanasi, Year of reprint 2006, Siddhi Sthana 6/61,62 p- 1241

8. Agnivesha, Charaka Samhita, revised by Charaka and Dridhbala with "Ayurveda Dipika" commentary by Chakrapani, Edited by Dr. Bramhanand Tripathi, Acharya, Published by Chaukhamba Surbharati Prakashan, Varanasi, Year of reprint 2006, Siddhi Sthana 7/5, p- 1249

9. Agnivesha, Charaka Samhita, revised by Charaka and Dridhbala with "Ayurveda Dipika" commentary by Chakrapani, Edited by Dr. Bramhanand Tripathi, Acharya, Published by Chaukhamba Surbharati Prakashan, Varanasi, Year of reprint 2006, Siddhi Sthana 6/4, p- 44

10. Ambika Dutta Shastri, Sushruta Samhita Chikitsasthana 34/16, 15th edition, 2002, Chaukhamba Sanskrit Sansthana, Varanasi, p 187

11. Ibidem; Chikitsa Sthana 36/36 p 196

12. Vagbhatta, Ashtanga Hridaya, Edited by Dr. Bramhananda Tripathi, Nidanasthana 8/7 Published by Chaukhamba Sanskrit Pratisthan, Delhi, reprint 2012, page no. 484

13. Kashyapa Samhita by Vriddha jivaka, revised by Vatsya with Sanskrit introduction by Nepal Rajguru Pandit Hemraj
Sharma, edition reprint 2002 Chaukhamba Sanskrit Sansthan, Pune, Garbhini-chikitsa adhyaya, Page no. 95

14. Ambika Dutta Shastri, Sushruta Samhita, Dalhana Chikitsa Sthana 34/16, 15th edition, 2002, Chaukhamba Sanskrit Sansthana, Varanasi, p 187

15. Ashtanga Sangraha Translated by Prof. K. R. Srikantha Murthy, Chaukhamba Orientalia, Varanasi, Volume 2, Edition 5, reprint 2005, kalpa Sthana 3/9 Page no.370.

16. A manual of Ksharasutra karma by Prof. Ramesh Chandra Arya $.1^{\text {st }}$ edition page no. 85

17. Bailey \& love, Short practice of surgery Edited by Norman S. Williams Christopher J.K. Bestrode \& P. Ronan o Connell, Edition 25 , page 74

18. A concise textbook of surgery by Dr. S. das, 8th edition, chapter 5, page 1083 .

19. SRB's Manual surgery by Sriram Bhat $M, 3^{\text {rd }}$ edition, year 2009, chapter 25 , page 911.

20. Chakrapani virchita Chakradatta, Vrana Shotha chikitsa/25, Page no.259 Published by Chaukhamba Sanskrit Sansthan, Varanasi, Year of Publication 2014.

21. Journal of Pharmaceutical and Scientific Innovation, Fissure in ano: A clinical approach, by Dr. Ashish Soni.

22. Sharma, P.V. Dravya-guna Vijanana. Vol. II. Page - 664; Chaukhamba Bharati Academy. Varanasi.2001.

23. Sharma, P.V. Dravya-guna Vijanana. Vol. II. Page - 666; Chaukhamba Bharati Academy. Varanasi.2001.

24. Sharma, P.V. Dravya-guna Vijanana. Vol. II. Page - 668; Chaukhamba Bharati Academy. Varanasi.2001.

25. Sharma, P.V. Dravya-guna Vijanana. Vol. II. Page - 680; Chaukhamba Bharati Academy. Varanasi.2001.

26. Sharma, P.V. Dravya-guna Vijanana. Vol. II. Page - 670; Chaukhamba Bharati Academy. Varanasi.2001.

27. Chakrapani virachita, Chakradatta. vrana shotha chikitsa/91 Page no.265, Published by Chaukhamba Sanskrit Sansthan Varanasi, Year of publication 2014

28. Sharma, P.V. Dravya-guna Vijanana. Vol. II. Page 579 Chaukhamba Bharati Academy. Varanasi.2001.

29. Sharma, P.V. Dravya-guna Vijanana. Vol. II Page521 Chaukhamba Bharati Academy. Varanasi.2001

30. Sharma, P.V. Dravya-guna Vijanana. Vol. II. Page 537 Chaukhamba Bharati Academy. Varanasi.2001

31. The Ayurvedic Pharmacopoeia of India. Part I, Vol 2. Govt. of India, Ministry of Health and Family Welfare, DISM \& H, New Delhi, 2001.

32. Sharma, P.V. Dravya-guna Vijanana. Vol. 3. Chaukhamba Bharati Academy. Varanasi.2001

33. A concise textbook of surgery by Dr. S. Das, $8^{\text {th }}$ edition chapter 45 , page 1083

\section{Cite this article as:}

Chandrakar Smriti, Rajpoot Purnima, Sahu Purnesh, Singh Balendra. Efficacy of Durvadi taila and Avgahana sweda by Dravya of Nayogradhadi gana in the management of Parikartika with special reference to Fissure-in-ano: A review article. Int. J. Res. Ayurveda Pharm. 2017;8(1):14-17 http://dx.doi.org/ $10.7897 / 2277-4343.0814$

Disclaimer: IJRAP is solely owned by Moksha Publishing House - A non-profit publishing house, dedicated to publish quality research, while every effort has been taken to verify the accuracy of the content published in our Journal. IJRAP cannot accept any responsibility or liability for the site content and articles published. The views expressed in articles by our contributing authors are not necessarily those of IJRAP editor or editorial board members. 